APEC: The F uture Prospects for a Bridge Spanning the Pacific

Tomoyoshi Nakajima

N ovember, 2010

Niigata, J apan

ECONOMIC RESEARCH INSTITUTE FOR NORTHEAST ASIA 


\title{
APEC: The Future Prospects for a Bridge Spanning the Pacific
}

\author{
Tomoyoshi Nakajima \\ Economic Research Institute for Northeast Asia (ERINA)
}

2009 saw the 20th anniversary of the formation of APEC. The steps taken by APEC-which raised an "Open Regionalism" aiming at the liberalization of trade and investment indicated by the Bogor Goals for the economic development of the Asia-Pacific region-have not been even, and the results have not always fulfilled the hopes of many members.

Today, many of APEC's members have concluded bilateral or regional FTAs with countries and territories within and without the region, and have realized the liberalization of trade and investment by means of exclusive frameworks. Moreover, in East Asia, which is an important part of APEC, regional economic integration is being sought by means of frameworks such as ASEAN Plus Three and ASEAN Plus Six. Such moves have an impact on the United States, which runs the possibility of being excluded from them, and has induced major changes in its East Asian trade policy. Today, as a specific response thereto, the United States is proposing an FTA or FTAAP, with its area being APEC in its entirety.

In this paper, on the premise of such changes in the environment, and in the area of the liberalization of trade and investment, we would like to look to the future of APEC, which is a unique international organization linking East Asia and the United States.

\section{Overview of APEC}

The forum on Asia-Pacific Economic Cooperation (APEC), via a call from Australian Prime Minister Bob Hawke, was formed in 1989 as an 
organization for the Asia-Pacific region's economic development and regional cooperation. Initially it had 12 countries as its members, including Japan, the United States, and Australia (Figure 1). Subsequently the membership increased, and currently it has expanded to 21 countries and territories, including China and Russia. In terms of economic scale, in 2008 it accounted for $53 \%$ of global GDP, and $43 \%$ of total trade. ${ }^{1}$

Figure 1: The Member Economies of APEC

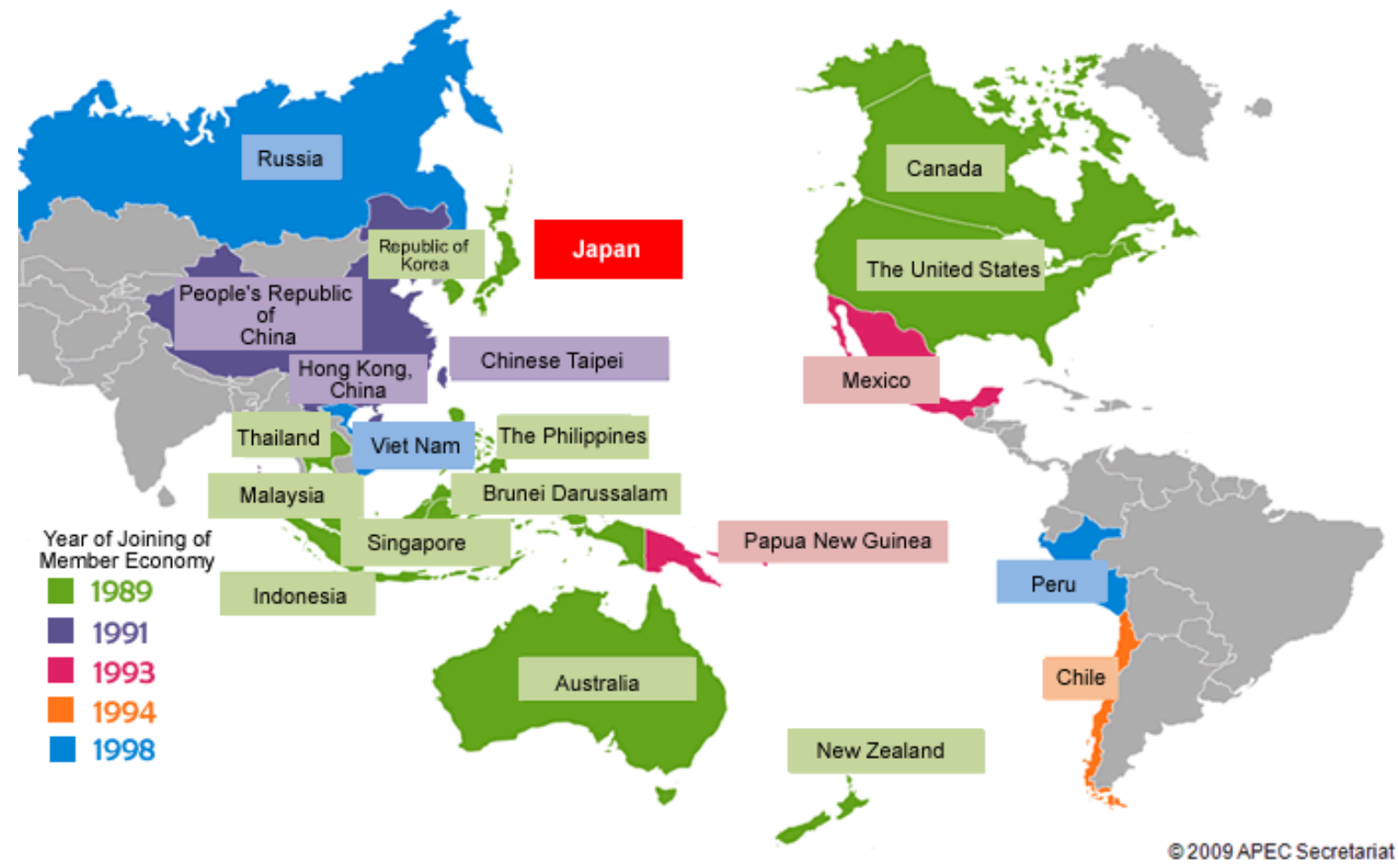

Source: Ministry of Economy, Trade and Industry (METI)

APEC, at the summit held in Bogor in Indonesia in 1994, came to agreement on the Bogor Goals regarding the liberalization of trade and investment. The content was that "the industrialized economies will achieve the goal of free and open trade and investment no later than the year 2010 and the developing economies no later than the year 2020."

\footnotetext{
${ }^{1}$ From Ministry of Economy, Trade and Industry website.
} 
The members of APEC, toward the achievement of these goals, have been undertaking activities with the following three areas (the Three Pillars of APEC) as their basic philosophy.

- Trade and Investment Liberalization

- Business Facilitation

- Economic and Technical Cooperation

In addition, APEC espouses an "Open Regionalism", and the results which have been realized via the liberalization of intraregional trade and investment are, via the principal of most-favored nation status, that they have adopted the principle of this being applied even to nations outside the region.

APEC has created multilevel mechanisms to realize these objectives (Figure 2). The APEC summit which is held annually in autumn, and the ministerial meetings which are held as advanced preparation for the former, form the core of the organizational structure. In addition, there are ministers' meetings for each sector, including trade, energy, small and medium-sized enterprises (SMEs), and telecommunications, and below these meetings of experts have been set up to tackle policy issues for a large number of areas (Figure 2). Other than these, the APEC Business Advisory Council has been set up as an advisory body to make recommendations from the business world within the region to the APEC summit. 
Figure 2: APEC Organizational Structure

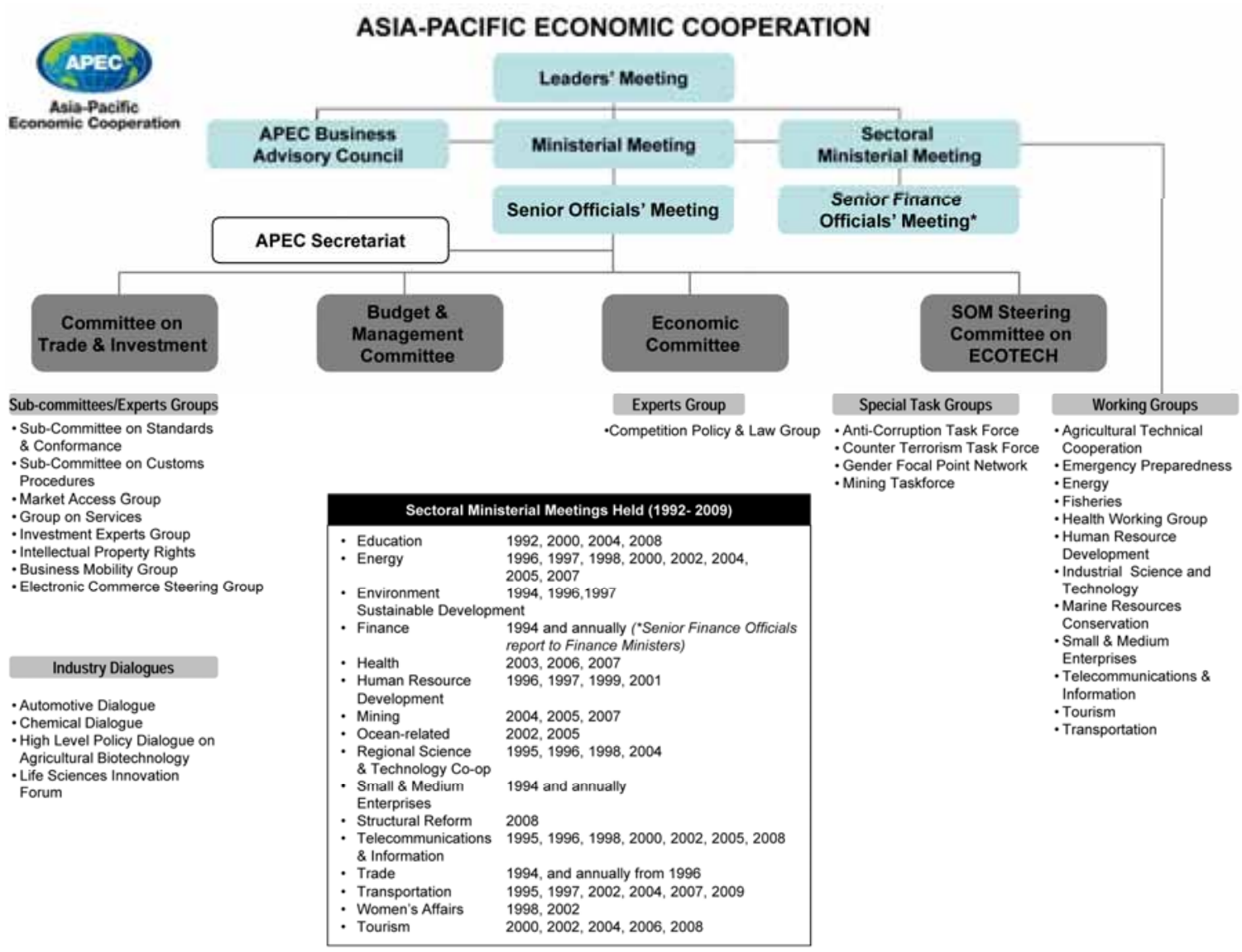

Source:APEC website

\section{APEC and US Participation}

The United States, as one of the founding members of APEC, has taken a position of leading its activities from the outset. When looking back at the last twenty years, however, the fruit in policy terms which has been yielded via APEC activities has not always satisfied the expectations of the United States. Amid such a reality, it has become a matter that is shaded depending on both the participation in and expectations from APEC of the United States. Below we shall look back on US participation in APEC based on the summarization by Terada (2009).

In the first period (1989-1995) of the initial formation of APEC, the 
United States actively participated in its activities, including hosting the first summit for APEC in 1993 in Seattle. Amid this, the United States aimed at creating some kind of legally binding force for APEC regarding agreement on the liberalization of trade and investment, yet was unable to obtain the approval of the other members. As a result, at the second summit in 1994 in Bogor, Indonesia, the Bogor Goals were established as an agreement without binding force.

In the second period (1996-2000), the United States, toward the realization of the Bogor Goals, aimed at the realization of Early Voluntary Sectoral Liberalization (EVSL) to come into force early in specific sectors, but the substantive results were poor owing to the passive positions of Japan and others.

Going through such developments, it is thought that the United States came to have doubts over the effectiveness of APEC as an arena for realizing the liberalization of trade and investment. Amid this, the September 112001 terrorist attacks occurred, and the United States selected an agenda to discuss security issues, including counter-terrorism measures, at the APEC forum (the third period (2001-2005)). The effective results for counter-terrorism measures, however, were poor, and again this sort of US position led to invoking the opposition of Asian countries who regarded APEC's role as a forum for discussing economic matters.

Meanwhile in the third period, even within the APEC region which had espoused "Open Regionalism", the concluding of bilateral FTAs ${ }^{2}$ of an exclusive nature, etc., had increased. In addition, the international environment surrounding APEC was being greatly transformed,

\footnotetext{
2 The Japanese government refers to a free-trade agreement that includes varied matters-such as investment, labor movement, intellectual property rights and standards' certification, and not only trade in commodities and services-as an Economic Partnership Agreement (EPA). However, as shown by NAFTA for example, many FTAs in recent years deal with items other than trade in commodities and services under that appellation. Consequently, in this paper, other than for the proper names for individual agreements, the term FTA is used.
} 
including that discussion on East Asian economic integration would be commenced within frameworks such as ASEAN Plus Three (Japan, China, and the ROK) ${ }^{3}$ and ASEAN Plus Six (Japan, China, the ROK, India, Australia, and New Zealand). ${ }^{4}$

In the fourth period (from 2006), affected by these changes in environment, the United States came to make the counterproposal of a Free Trade Area of the Asia-Pacific (FTAAP) at APEC.

Here the bidding farewell to the concept of "Open Regionalism" became clear. In the following section we shall summarize in more detail the background surrounding the FTAAP, from this fourth period on.

\footnotetext{
${ }^{3}$ A framework for economic integration by a total of 13 countries: the 10 ASEAN nations, Japan, China, and the ROK. The ASEAN Plus Three Summit Meeting has been held since 1997. They have realized several economic cooperation measures, such as the Chiang Mai Initiative, a currency swap arrangement to stave off a currency crisis. As for an FTA concept within the region, there is an EAFTA (East Asia Free Trade Agreement), and after joint research it was agreed at the 2009 summit to have intergovernmental discussion thereon.

${ }^{4}$ A framework for economic integration by a total of 16 countries: the 10 ASEAN nations, Japan, China, the ROK, India, Australia, and New Zealand. The East Asia Summit (EAS) has been held from 2005. As for an FTA concept within the region, there is a CEPEA (Comprehensive Economic Partnership in East Asia), and after joint research it was agreed at the 2009 EAS to have intergovernmental discussion thereon.
} 
Table 1: The Changes in the United States' Involvement in APEC

\begin{tabular}{|c|c|}
\hline Period & Major Development(s) \\
\hline $\begin{array}{l}\text { First period } \\
(1989-1995)\end{array}$ & $\begin{array}{l}\text { As the host country for the first APEC summit in } \\
\text { 1993, the United States heightened the international } \\
\text { importance of APEC. At the subsequent summit in } \\
\text { Bogor, Indonesia, however, it attempted to make the } \\
\text { main topic the liberalization of trade and investment, } \\
\text { but it failed in making it have a legally-binding force. } \\
\text { The non-binding Bogor Goals were adopted. }\end{array}$ \\
\hline $\begin{array}{l}\text { Second period } \\
(1996-2000)\end{array}$ & $\begin{array}{l}\text { Regarding the realization of the Bogor Goals, at the } \\
\text { summit in Manila in } 1996 \text { the United States had to } \\
\text { suffer the adoption of a method for the } \\
\text { implementation of liberalization made up from } \\
\text { Individual Action Plans (IAPs) and Collective Action } \\
\text { Plans (CAPs). Regarding the content (marine and } \\
\text { forestry products) of Early Voluntary Sectoral } \\
\text { Liberalization (EVSL) to come into force early in } \\
\text { specific sectors, however, it didn't get the agreement } \\
\text { of Japan, and the qualitative results of liberalization } \\
\text { were poor. }\end{array}$ \\
\hline $\begin{array}{l}\text { Third period } \\
(2001-2005)\end{array}$ & $\begin{array}{l}\text { Hit by the September } 112001 \text { terrorist attacks, the } \\
\text { United States established an agenda to handle } \\
\text { security issues in the APEC arena also, yet no results } \\
\text { appeared, and it invoked the opposition of Asian } \\
\text { countries who regarded APEC's role as a place for } \\
\text { discussion concerning economics. }\end{array}$ \\
\hline $\begin{array}{l}\text { Fourth period (from } \\
2006 \text { ) }\end{array}$ & $\begin{array}{l}\text { The United States called for an FTAAP, having APEC } \\
\text { as its area, and aimed toward a liberalization of trade } \\
\text { and investment, having the legally-binding force of an } \\
\text { FTA. }\end{array}$ \\
\hline
\end{tabular}

Source:Compiled by the author with reference to Terada (2009) 


\section{FTAAP}

At the fourteenth APEC summit held in Hanoi, Vietnam, in November 2006 the concept was raised of an FTAAP (Free Trade Area of the Asia-Pacific)_an FTA covering APEC in its entirety-and the undertaking of examination thereof as a "long-term prospect" was incorporated in the declaration adopted. According to Sugawara (2006), in the case of the FTAAP concept itself, at the time it wasn't the first occasion it had been raised in the APEC arena. In the first place, ABAC (the APEC Business Advisory Council), an organization making proposals from the business world's standpoint to APEC, proposed it at the twelfth APEC summit held in Santiago, Chile, in 2004. At that forum, however, many objections were voiced, and it wasn't taken as a subject for active discussion. Furthermore, at the thirteenth APEC summit also-in Busan, the ROK-it got similar treatment.

Such a passive response, and to this concept, is thought to be because there are two big problems: the construction itself of an FTA covering all the territory of APEC, which constitutes half of global GDP, is difficult; and an FTA which has discriminatory workings toward those outside the region will be fundamentally in contradiction with the APEC stance which has until now espoused "Open Regionalism".

The reason for the FTAAP concept being raised abruptly in 2006 as a subject of discussion is because the United States shifted its policy in the direction of promoting this concept. ${ }^{5}$ We shall below analyze the background behind why such a policy shift was undertaken.

C. Fred Bergstein of the Peterson Institute for International Economics, a Washington DC think tank, is known as a proponent of the FTAAP concept. The points expected as the aims of an FTAAP, indicated in Bergsten (2007), are given below. In regard to these items, although

\footnotetext{
${ }^{5}$ President Bush, in a speech at a university he visited in Singapore prior to the Hanoi summit, called an FTAAP a concept worthy of serious consideration.
} 
not necessarily being ones which represent the opinions of the then Bush administration, the adding of their examination is considered useful as they summarize the benefits that an FTAAP brings the United States, and further deciphers the reasons for the policy shift of the Bush administration.

i) A catalyst for the success of the Doha Round

ii) A contingency plan (Plan B) for trade liberalization in the event of the failure of the Doha Round or its becoming stymied

iii) Prevents the occurrence of discrimination or disharmony in new trade in the Asia-Pacific region, via the further proliferation of bilateral and regional FTAs

iv) Avoids the risk of East Asia (or the Western Hemisphere) "drawing a line down the middle of the Pacific", splitting the Asia-Pacific region

v) Improvement of US-China economic friction

vi) The revitalizing of APEC itself

vii) Forces a continuation in engagement in the US's trade problems in Asia and globally

What is seen as important amongst these is the aim of "avoiding splitting the Asia-Pacific region" in $i v$. If we were to consider the point that support for an FTAAP from the Bush administration had been hammered out amid the heightening discussion of East Asian economic integration in the shape of ASEAN Plus Three and ASEAN Plus Six, etc., then it would be within reason to consider that such thinking was behind policy formation.

Concerning $i$, on the other hand, it could be called a way of thinking aimed at reenacting the case where APEC's one-time moves toward the Bogor Goals stimulated the then EC, and pushed forward the Uruguay 
Round which had been making little headway. As for the practical problems, however, regarding the realization of an FTAAP, the difficulty overtaking consensus building at the Doha Round is something to be anticipated. In addition, by only creating a concept, like at the time of the Uruguay Round, it is doubtful that it would function as a draw for countries outside the region, such as Europe. It is thought that the current situation of APEC, with the virtual collapse of the Bogor Goals, will further reduce such an effect. Consequently, that the Bush administration attempted a policy shift with this as a major aim is something hard to contemplate.

Moreover ii may be called a way of thinking that complements $i$. Among the others, iii, $v$, vi and vii are respectively not so much the principal objectives of the formation of an FTAAP; rather it may be said that it is apt to think of them as effects that are to be hoped for secondarily.

Considering these matters overall, behind the shift in policy of the Bush administration it can be seen, as shown by $i v$, that there was an intention of curbing East Asian economic integration.

The Democrat Obama administration, which commenced in 2009, initially had its hands full with responding to the economic crisis following the Lehman shock, and the constructing of its own trade policy was delayed. Entering the second half of 2009, however, in similar fashion to the preceding administration, a position that stressed an FTAAP became clear. At the seventeenth APEC summit held in Singapore in November, the continuation of examination of the concept of an FTAAP was incorporated in the declaration, via a US initiative. Thereby it has been shown that the concept of an FTAAP has not been changed, even after going through a change of administration, and is the linchpin of US East Asia trade policy.

In Japan meantime, the Hatoyama administration commenced in 
September 2009, centered on the Democratic Party of Japan. In "The New Growth Strategy (Basic Policies)" which the administration announced in December of the same year, it was specified that "Japan will take advantage of its role as the host economy of the 2010 Asia-Pacific Economic Cooperation (APEC) meetings and utilize the APEC framework to prepare a roadmap toward the establishment of the Free Trade Area of the Asia-Pacific (FTAAP), with 2020 as a target year."

Table 2: Moves concerning FTAAP and TPP

\begin{tabular}{|c|c|l|}
\hline Year & Month & \multicolumn{1}{c|}{ Particulars } \\
\hline 2004 & November & $\begin{array}{l}\text { At the 12th APEC summit held in Santiago, Chile, ABAC } \\
\text { proposed an FTAAP }\end{array}$ \\
\hline 2006 & November & $\begin{array}{l}\text { At the 14th APEC summit held in Hanoi, Vietnam, an } \\
\text { FTAAP was raised as a topic for discussion }\end{array}$ \\
\hline 2009 & September & $\begin{array}{l}\text { The Office of the United States Trade Representative } \\
\text { officially announced participation in the TPP }\end{array}$ \\
\cline { 2 - 4 } & November & $\begin{array}{l}\text { US President Obama officially announced participation } \\
\text { in the TPP in a speech in Tokyo } \\
\text { continuation of examination of the concept of an FTAAP } \\
\text { was incorporated in the declaration }\end{array}$ \\
\cline { 2 - 4 } & December & $\begin{array}{l}\text { In "The New Growth Strategy (Basic Policies)" which the } \\
\text { Hatoyama administration announced, it was specified } \\
\text { that Japan would prepare a roadmap toward the } \\
\text { establishment of an FTAAP, with 2020 as the target year }\end{array}$ \\
\hline 2010 & March & $\begin{array}{l}\text { The first negotiations began for the expansion of the } \\
\text { TPP to also add the United States and other nations }\end{array}$ \\
\hline
\end{tabular}

Source: Compiled by the author from various materials 
Figure 3: Major FTAs related to APEC Member Economies

(including those at the conceptual stage)

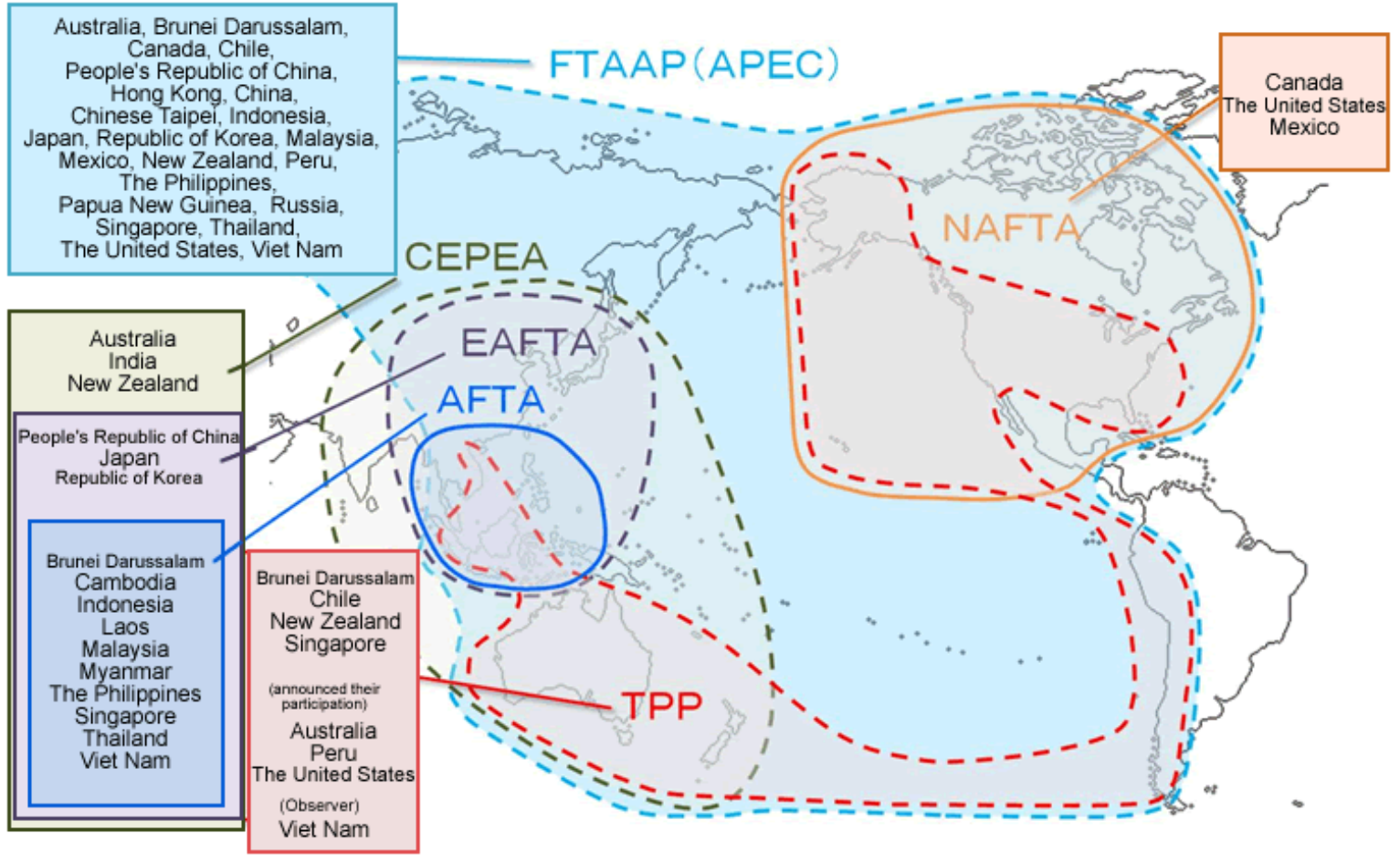

Source: Ministry of Economy, Trade and Industry (METI)

\section{TPP}

As above, it would appear that, throughout both the Bush and Obama administrations, the position of the United States has been consistent, holding fast to an FTAAP as the core of its East Asia trade policy.

On the other hand, however, for the realization of an FTAAP which will include diverse countries and territories, it can also be foreseen that it will take a long time. For the United States, it appears that at the same time alternative proposals are also needed, which can bring real economic results in a shorter period of time. Regarding these, Barfield (2007) has presented four scenarios which it is possible that the United States will subsequently adopt. 
i) Promote bilateral FTAs with the countries of East Asia in the future as well

ii) Aim for voluntary FTAs among the member states and territories of APEC

iii) Aim for the realization of FTAAP

iv) Observe the situation for the foreseeable future, and in cooperation with allies such as Japan, the ROK and Singapore, respond in the event of some kind of move occurring.

Among the above, $i$-being a matter which will continue the course of past bilateral FTAs which have progressed with the countries of ASEAN, and the ROK, etc.-can, as an option, be called the most conservative. Meanwhile iii, as introduced above, will be a long-term strategy.

Proposal $i i$ is a compromise proposal between $i$ and $i i i$, and offers the benefit of combining the two strong points of a presentation of a global vision, and a stepwise approach. On this point it has been considered that, in the sense of complementing iii, the possibility is high of its being chosen as a policy option.

Indeed the Bush administration in September 2008 announced participation in the Trans-Pacific Strategic Economic Partnership (TPP), an FTA by the four countries of Singapore, New Zealand, Chile and Brunei. Subsequently Australia and Peru also announced their participation in the same agreement, ${ }^{6}$ and it can certainly be rated a "voluntary FTA" in the words of Barfield.

Accompanying the changeover to the Obama administration, US participation in TPP deliberations has been delayed from the original plan. President Obama, however, in the speech he gave while visiting Tokyo ahead of the APEC summit in November 2009, announced the promotion of the TPP. In March 2010 the United States also took part,

${ }^{6}$ Vietnam has also announced its participation in the TPP as an observer. 
and official deliberations were commenced.

The United States has also called on Japan, and Malaysia and others who had been negotiating bilateral FTAs, to participate in the TPP, and has designated the TPP as the principal means for the foreseeable future in its East Asia trade strategy. If the member economies of APEC participating in the TPP go on increasing, following the United States' lead, it will become a factor promoting the substantiation of an FTAAP. Moreover the TPP, even in terms of content, for the most part does not accept commodities that are exceptions to the elimination of tariffs, and aspires toward an advanced FTA which aims at comprehensive agreements on such matters as services and investment. The height of that level will also have an impact on other FTA concepts in the Asia-Pacific region.

Whatever the direction for the TPP, it will have a major influence on the future of APEC.

\section{Conclusion}

As above, in this paper we have looked back on the developments concerning APEC, centered on dealings with the United States. It can be said that the commencement of discussion concerning an FTAAP in 2006 has revealed-in the most important sphere of the liberalization of trade and investment-the reality that the concept of APEC's "Open Regionalism" has become a dead letter. The United States is clearly aiming at utilizing APEC as a means to vie with the frameworks for East Asian economic integration of ASEAN Plus Three and ASEAN Plus Six, etc. The "voluntary-FTA" TPP is taking on that complementary role.

As stated above, present-day APEC has a multitier organization, and has become a forum for the discussion of a variety of economy-related areas. Consequently, in the future also it will continue to hold a certain 
significance in the Asia-Pacific region. Regarding the regional liberalization of trade and investment which was the greatest objective for the establishment of APEC, however, the realizing of the Bogor Goals which raised "Open Regionalism" has been lost, and instead regional FTA concepts that include the TPP will come to take the lead role. Furthermore, in this situation, it can be said-concerning whether it can be realized in the long-term-that an FTAAP that covers the entire area of APEC intended by the United States is uncertain at the present point in time.

Now, Japan, under the Democratic Party of Japan administration, is attempting to place the promotion of an FTAAP via the forum of APEC at the center of its trade policy. On the other hand, however, there is the matter that the Democratic Party of Japan administration is also espousing active involvement in East Asian economic integration. ${ }^{7} \mathrm{As}$ is to be expected, a contradiction will likely arise between such strategic objectives. Moreover, regarding the success or failure of an FTAAP as a long-term objective, even if matters are left as they are for the time being, in the short term how will Japan tackle the TPP for which the United States is calling for cooperation? Certainly it can be called a situation where the establishment of a consistent strategy, throughout Japan's trade policy, is necessitated.

\section{Bibliography}

\section{In Japanese}

Sasaki, Takanari (2009) "Bei Obama seiken no Ajia Taiheiyō senryaku"

[The Asia-Pacific Strategy of the US Obama Administration], Chapter

3 in Shujiro Urata and Japan Center for Economic Research (JCER)

7 The policy "Strengthen Japan's foreign relations in Asia with the aim of building an East Asian Community" was included in the Democratic Party of Japan Manifesto for the general election of August 2009. 
(eds.) Ajia Taiheiyō kyodai shijō senryaku [Strategies for the Huge Asia-Pacific Market], Nikkei Publishing Inc.

Sugawara, Junichi (2006), "Totsujo fujō shita Ajia Taiheiyō FTA (FTAAP) kōzō-Shinten suru Higashi Ajia keizai tōgō-e no Beikoku no kan’yo" [The Suddenly Emerged Structure of the Asia-Pacific FTA (FTAAP) - The United States involvement in the unfolding economic integration of East Asia], Mizuho Research Institute, Mizuho Seisaku Insight [Mizuho Strategic Insight] published on 8 December 2006

Terada, Takashi (2009) "Beikoku to APEC no 20 nen" [The United States and Twenty Years of APEC], Chapter 2 in Shujiro Urata and Japan Center for Economic Research (JCER) (eds.) Ajia Taiheiyō kyodai shijō senryaku [Strategies for the Huge Asia-Pacific Market], Nikkei Publishing Inc.

\section{In English}

Barfield, Claude (2007), "US Trade Policy: The Emergence of Regional and Bilateral Alternatives to Multilateralism", Intereconomics Review of European Economic Policy, Vol. 42, No. 5, Springer

Bergsten, C. Fred (2007), "A Free Trade Area of the Asia-Pacific in the Wake of the Faltering Doha Round: Trade Policy Alternatives for APEC", in Charles E. Morrison and Eduardo Pedrosa (eds.) An APEC Trade Agenda?, Institute of Southeast Asian Studies (ISEAS), Singapore

Nakajima, Tomoyoshi (2008), "East Asian Economic Integration and US East Asia Trade Policy", ERINA Discussion Paper No. 0804e, Economic Research Institute for Northeast Asia (ERINA), Niigata, Japan 